\title{
The Development of Student Work Sheets Based on Reciprocal Teaching Models to Improve Critical Thinking Ability in Elementary School
}

\author{
Ria Erawati ${ }^{*} \quad$ Caswita $^{2} \quad$ Darsono $^{3} \quad$ Alben Ambarita ${ }^{4}$ \\ Faculty of Teacher Training and Education, University of Lampung \\ St. Soemantri Brojonegoro No.1Gedung meneng Bandar Lampung, Indonesia 35145
}

\begin{abstract}
This research and development aims to develop and describe the feasibility and effectiveness of student worksheets based on reciprocal teaching in improving students' critical thinking skills. The type of research that used is research and development that refers to the theory of Borg and Gall. The population of this study was fourth grade students of Elementary School in Bandar Sribhawono District. The study sample was 30 students of fourth grade in A class of Public Elementary School 2 Sribhawono who were determined by purposive sampling technique. The data was collected through questionnaire sheets, observation sheets and test questions. The results of the study show that student worksheets based on reciprocal teaching are feasible, and effective for improving students' critical thinking skills.
\end{abstract}

Keywords: Student worksheets, Reciprocal teaching,Elementary school

DOI: $10.7176 / \mathrm{JEP} / 10-17-11$

Publication date:June $30^{\text {th }} 2019$

\section{INTRODUCTION}

Education can be interpreted as a conscious and systematic effort to achieve a better standard of living. Education is the main factor determining the quality of human resources of a nation, therefore the progress of a nation can be measured by the progress of its education which is a means to create quality human resources. An efforts to improve the quality of a nation, there is no other way except through improving the quality of education.Based on this idea, the United Nations through the United Nations, Educational, Scientific and Cultural Organization (UNESCO) instituted four pillars of education both for the present and the future, that are: (1) learning to know, (2) learning to do (3) learning to be, and (4) learning to live together. The ability that must be possessed by students in education in the 21 st century is Creativy, Critical Thinking, Communication, and Collaboration (4C) Bialik (2015: 1).

The information obtained that the creativity of students is very necessary in creating new things and innovating for better learning outcomes. Critical thinking is active and skilled in conceptualizing, applying, analyzing, synthesizing and evaluating information collected from observation, experience, reflection, reasoning, or communication. Having critical thinking skills allows students to analyze their own thoughts to ensure that they have made choices and draw intelligent conclusions.This is in accordance with Elder and Paul in Romanowski (2012: 121), the best critical thinking is to understand their own thinking skills. This requires that they develop standard criteria to analyze and assess their own thinking skills and routinely use standard criteria to improve their quality. Whereas according to John Caffe (in Johnson, 2014: 187) defines critical thinking as thinking to systematically investigate the thinking process itself. De Porter, et al. (2013: 298) stated that critical thinking is one of the high-level skills that is very important to be taught to students in addition to creative thinking skills.

Furthermore, according to Johnson (2014: 187) critical thinking is thinking well, and pondering about the thought process which is part of thinking well. Critical thinking ability is not inherited from students, but is taught and nurtured formally and non-formally through learning practices that instill a critical and transformative perspective. More importantly, the development of critical thinking does not start from the learning process that moves from telling students what to think about, but developing critical thinking of students to dare to ask questions in the learning process in which there are values in education, culture, politics, and religion.Students who do not have the ability to think critically cannot decide for themselves what to think, believe, and how to act. This can cause students to imitate, adopt and accept the conclusions of others passively, therefore each student must have the ability to think critically. Critical thinking ability can be raised or improved through the learning process.

The curriculum that used in the current learning process is the Curriculum 2013. The curriculum 2013 is a curriculum based on competency which in formulates an integrated attitude, knowledge, and skills competencies that must be mastered by students. Learning in the curriculum 2013 has several themes that are applied in learning. Through contextual problems, students can learn from experience and the surrounding environment, therefore learning must be understood by students, not only memorized but students understand correctly the 
purpose and usefulness of the knowledge, Core Competence and Basic Competence in Themes can be achieved and applied in everyday life.Based on these provisions the teacher must try to make the students have willingness to learn so that the students apply actively and creatively optimally. The teachers must act as facilitators and students must be more active so that they can stimulate students to think critically. For the sake of the success in delivering learning material to the students, the teacher must apply a model and also make teaching materials, one of them is Student Worksheet. Consideration of choosing student worksheets to be developed in this study is due to material coverage and assessment student worksheets that used in the school are worksheets for the students that purchased from the market.

The student worksheets is more about cognitive knowledge, less in the field of affective and psychomotor. Of course this is not in accordance with the enactment of the Curriculum 2013 which emphasizes developing a balance between spiritual, social, knowledge and skills, and applying it in various situations in schools and society. The results of the Trends in International Mathematics and Science Study in 2015. the achievement position of fourth grade students showed that in Indonesia the scores obtained an average of 397 ranked 44th out of 56 countries. The assessment information on Trends in the International Mathematics and Science Study shows that the achievements of Indonesian students are still low.

This category requires students to master the concept well, can organize information, make announcements, solve non-routine problems, take and submit conclusions justification arguments. The domain of the average Indonesian score survey conducted by Trends in the International Mathematics and Science Study is knowing, applying, and reasoning. According to the 2015 Program International for Student Assessment survey, Indonesia ranks 68 out of 76 countries.

The fact that happened in Indonesia is that students' current critical thinking skills are still low. The survey conducted by the Organization for Economic Co-operation and Development in 2016 showed that the majority of Indonesian students have not been able to develop critical thinking skills. From year to year, Indonesia experienced an increase in the average score, but Indonesia was still ranked below. In 2009 Indonesia was ranked 5th from below, in 2012 Indonesia's average score rose but its ranking dropped to 2 from below and in 2015 Indonesia experienced an increase in the average score and ranked 9th from the bottom.

Based on the survey shows that students' critical thinking skills in Indonesia have increased despite being below the average score at the international level. According to Ibrahim in Istianah (2013: 45) to bring towards learning that can develop critical thinking skills must depart from learning that makes students active. The model is one of the answers that are indeed considered suitable to be applied in any curriculum, any field of study, and the class regardless of the circumstances. The learning model is one of the most important and influential factors in the learning process.

Reciprocal teaching learning model is one of the cooperative models in thematic learning. The reciprocal teaching model was originally designed to overcome learning difficulties in reading texts. This learning model was raised by Palinscar in 1982 when he found that some of his students had difficulty understanding a reading text. Palincsar and Brown in 1986. Arend (2012: 58) defines reciprocal teaching as a model in which teaching procedures are designed to teach students about cognitive strategies and help students understand the material well.A student can just read a set of letters that form a word but it turns out to understand the meaning of the text that is read is not as easy as reciting the reading. This is the background of the emergence of the reciprocal teaching model. This learning model applies four independent understanding strategies, that are collecting teaching materials, compiling questions and completing them, re-explaining the learning obtained, then summarizing the teaching material that has been obtained by the students.

Trianto (2012: 173) also defines that reciprocal teaching is a model with a constructivist approach to student learning strategies based on the principles of making / submitting questions where cognitive learning strategies are taught through direct teaching by teachers to improve reading performance students who read their understanding are low. According to Slavin (2011: 14), reciprocal teaching is a small group teaching model that is based on the principle of formulating questions through teaching and example giving, teachers grow the ability of metacognition especially to improve reading performance of students who have poor understanding.

According to Taylor et al (in Yen-Ju Hou, 2015: 16) reciprocal teaching a multi-strategy approach used to teach reading comprehension, is a technique that is considered effective in helping students become active learners by reading for understanding. This is supported by a study from Yousef (2016: 72) which states that the model of reciprocal teaching teaching has been designed for students who have difficulty reading, and explains that the model is effective for increasing the level of reading comprehension.

Student worksheets are the easiest to use print learning materials. Student worksheets are very well used in the framework of heuristic and expository strategies. The heuristic strategy of student worksheets is used in guided discovery models, while in the expository strategy the student worksheets are used to provide development training. This was stated by Lee (2014: 96) student worksheets can be useful in terms of academic achievement. For example, as a support for textbooks. Student worksheets can be used to add information to a particular class. In addition, students' worksheets can be used by students to construct knowledge. 
Furthermore, by paying attention to the teaching materials that used when the researcher made observations, the problem exercises that used were sourced from the students 'books and also the students' worksheets. Student worksheets that used by the students have not led students to experience firsthand, so that students cannot develop their critical thinking skills because the student worksheets that used are from the publisher and are not made directly by the teacher so that they are not in accordance with the needs of students. Even though the school has used the curriculum 2013 with the scientific approach and the learning model that has been set, learning that is carried out by educators is oriented only to the completion of the material contained in the book alone and less related to the experience experienced by direct learners.

So that students' critical thinking skills are not developed optimally. Based on the needs analysis obtained from questionnaires obtained results that $100 \%$ of educators have never applied learning based on the reciprocal teaching model. Based on this background, the researcher intends to use the reciprocal teaching model in improving the learning process in order to obtain the desired results so that it can improve critical thinking skills in theme 6 of my ideals through the reciprocal teaching model in fourth grade ofElementary School in Sribhawono District.

\section{METODS}

This study uses research and development referring to the theory of Borg \& Gall (1983: 772) on Reasearch \& Development according to the research objectives, namely research procedures with the aim of developing and validating educational products developed. Borg and Gall (2003: 569-575) research procedures and development, namely research and information collecting, planning, developing preliminary form of product, preliminary field testing, main product revision, playing field testing, operational product revision, operational field testing, final product revision, and dissemination and implementation. until the seventh step, because of the limitations of researchers, both in terms of time and cost.

The study population was fourth grade students of the Sribhawono District Elementary School who had implemented the 2013 curriculum. The sample was determined using purposive sampling with the consideration that SDN 2 Sribhawono as a school for the 2013 curriculum implementation model was 30 students.

Data collectors use questionnaires, namely material and media validation. The material aspects of the worksheet include conformity with the 2013 model and curriculum, and quality of content. The media aspect of the worksheet fulfills didactic, construction, and technical requirements. Learning outcomes were obtained from the results of the pretest and posttest of learning using worksheets oriented to reciprocal teaching models, using valid and reliable test instruments, and considering the level of difficulty and the power of different questions. Multiple choice instruments are given a score of 1 for correct answers and a score of 0 for wrong answers.

The results of learning critical thinking skills using an observation sheet. Product effectiveness test is carried out to see the existence of students' critical thinking abilities seen from the learning outcomes of students before and after learning using reciprocal teaching based worksheets. N-Gain is used to analyze the increase in critical thinking learning outcomes before and after learning using reciprocal teaching based worksheets.

\section{RESULTS AND DISCUSSION}

\subsection{Results}

The results of the research and development of student work sheets based on recoiprocal teaching on thematic learning of fourth grade students of SDN 2 Sribhawono, product development with the development procedure referring to the development model of Borg \& Gall (2003: 569-575) obtained the following results.

\subsubsection{Research and information collecting}

The initial information collection was carried out through preliminary research by identifying the learning process and collecting learning outcomes in grade IV elementary school in Bandar Sribhawono District. The results of the preliminary research are used as a consideration and the basis for developing student worksheets. This step needs to be done because this development research tests a teaching material in the form of student work based on Reciprocal Teaching whose development must be based on empirical data about the profile and subject under study. Based on the observation results of the analysis of student learning outcomes and the analysis of the needs of educators in September 2018 in the fourth grade of elementary school in Bandar Sribhawono District.

\subsubsection{Planning}

Planning from the development of student worksheets based on reciprocal teaching, namely, the preparation of student worksheet frameworks based on reciprocal teaching, presentation of material tailored to the steps, planning evaluation tools, and preparation of assessment instruments.

\subsubsection{Development preliminary form of product}

Steps for developing student worksheets are 1) Assessment of material in the student worksheet, 2) Drafting of student worksheets based on Reciprocal Teaching. The development of the initial product format was carried out in accordance with the framework of the student worksheets that had been completed consisting of a) cover page 
including: (i) title determined based on the design stage, (ii) the name of the student worksheet, Ria Erawati, (iii) Identity of student worksheets for administrative needs, (iv) supporting drawings to briefly describe the contents of student worksheets that are drawn to briefly describe the contents of the student worksheet developed, (v) target users of student worksheets developed, b) preface, c) table of contents, d) mapping of basic competencies, e) learning objectives, f) preparation of the contents of student worksheets.

\subsubsection{Tes the initial product}

Initial product trials were carried out by material experts, media experts, and validation of fourth grade educators. The results of material validation by material experts obtained a value of 77.50 for the first validation and 95.00 for the second validation. The results of media validation by media experts obtained the value of the first validation 88.00 and the second validation 93.00. Validation test for elementary school fourth grade educators has a value of 90.00. Suggestions and input from validation experts, namely indicators developed so that more intact material is obtained by students, thematic learning so that information needs to be related to various subject matter, complete image support related to material, fixing documentation cover images, learning objectives, reading discourse (give a picture of supporters ) After the product was revised, a small group trial was conducted in class IV B of SDN 2 Sribhawono. Small group assessments are carried out by 10 students consisting of low, medium and high-ability students.

\subsubsection{Revision of Initial Products}

Based on the results of testing of student worksheets based on reciprocal teaching in small groups, the results were an increase in critical thinking skills and student learning outcomes. So this student worksheet based on reciprocal teaching was not revised, and was feasible to be tested in large groups.

\subsubsection{Test the main product}

The subjects of the large group trial were 30 students of class IV A of SDN 2 Sribhawono. Before the learning activities in the first meeting students first carry out the pretest and posttest at the sixth meeting. This is intended to see the effectiveness of student worksheets based on reciprocal teaching whether there is an increase in learning outcomes before and after learning is done by using student worksheets based on reciprocal teaching. Observation of Critical Thinking Ability using assessment of critical thinking skills obtained from the results of student observations during learning activities runs using student worksheets based on reciprocal teaching. The results of observations of critical thinking skills of 30 large group students are 1 student (3.34\%) very good category, 25 students $(83.33 \%)$ with good categories, 4 students $(13.33 \%)$ with quite good categories, and no students with less categories. The data shows that students' critical thinking skills both during the learning process use student worksheets based on reciprocal teaching.

\subsubsection{Revised Final Products}

Based on large group trials, the results of increased critical thinking skills and student learning outcomes were obtained. Student learning outcomes, material expert validation, media experts and practitioners are the references in making conclusions that student worksheets based on reciprocal teaching are not revised and are feasible to implement.

\subsubsection{Test the effectiveness of student worksheets}

Product effectiveness test is conducted to see the existence of students' critical thinking abilities seen from the learning outcomes of students before and after learning using worksheets based on reciprocal teaching. The average learning outcomes of pretest students in fourth grade in A class is 56.67 and the posttest results of students increase to 78.67 and the average N-Gain results show a result of 0.51 which means that normalized gain is in the classification of "moderate", then the level of effectiveness is effective. It can be seen that students 'worksheets based on reciprocal teaching are effective in fostering students' critical thinking skills.

\subsection{Discussion}

\subsubsection{The development of student worksheets}

The development of student worksheets based on reciprocal teaching in thematic learning focused on fourth grade themes 8 Areas of My Abode with sub-themes 1 My Abode Environment. The development of student worksheets based on reciprocal teaching adapted from the R \& D step by Borg \& Gall (1983: 784) by using seven out of ten steps. The first stage was the initial research and information gathering, after the researcher found out the problem the researcher planned to develop the sheet. reciprocal taching based student work that will be used by students so that it can improve critical thinking skills seen from the learning outcomes of students.

Furthermore, the researcher compiled the development of the initial product of the worksheet of the students, in this step the researcher poured the pattern of developing the content and design of student worksheets based on reciprocal teaching in accordance with the steps of reciprocal teaching. The next stage is the initial trial. This stage the researcher conducted a validation test and a small group trial. The validation test was carried out by three validators, that are matrians, media experts, and fourth grade educators with the aim of validating the product being developed whether it was in accordance with the development requirements so that 
it was feasible to be tested. The results of material validation by material experts obtained a value of 77.50 in the first validation and 95.00 in the second validation. The results of media validation by media experts obtained the value of the first validation 88.00 and the second validation 93.00. Validation test for elementary school fourth grade educators obtained a value of 90.00. The researcher conducted a product revision for suggestions and comments from the validators. After the product is declared valid and feasible to be tested, then the next stage is a small group trial involving ten students.

The results obtained based on the pretest and posttest have an increase in the results of students' critical thinking learning. Then the researcher made a revision to improve the product. The next stage of the field trial, reciprocal teaching based student worksheet products were piloted in the learning process. This field trial stage was used to determine the effectiveness of student worksheets based on reciprocal teaching in improving critical thinking skills seen from the learning outcomes of students at the pretest and posttest. Based on the results of the effectiveness test that has been done, data obtained from the increase in student learning outcomes before and after using the worksheet based on reciprocal teaching students. Therefore, this reciprocal teaching based worksheet product is not revised and is feasible to implement.

\subsubsection{The effectiveness of student worksheets based on Reciprocal Teaching}

The effectiveness test is conducted to determine the effectiveness of student worksheets based on reciprocal teaching in the learning process that has been done and the learning outcomes of students which refers to the ability to think critically. The effectiveness test is used to see critical thinking skills, and student learning outcomes. The effectiveness test was carried out on 30 students of fourth grade in A class of Public Elementary School 2 Sribhawono. The student worksheets that were tested included the theme material of My Place Area, My First Place Environmental Sub-theme that had been designed before. The results of observing critical thinking skills in small groups were 10 students in small groups, there were 1 student $(10 \%)$ with very good categories , 4 students (40\%) with good categories, 5 students $(50 \%)$ with fairly good categories, and no students with less categories.

In large groups there are 1 student (3.34\%) in the very good category, 25 students $(83.33 \%)$ with good categories, 4 students $(13.33 \%)$ with a fairly good category, and no students with less category. Based on the learning outcomes test, it can be seen that there is an increase in students' critical thinking skills in small groups and large groups after using student worksheets based on reciprocal teaching. The effectiveness of teaching materials can be seen from the increase in student learning outcomes after using the given teaching material. To determine the effectiveness of using reciprocal teaching-based student worksheets on critical thinking skills by looking at student learning outcomes before and after using worksheets of reciprocal teaching students.

Student worksheets based on reciprocal teaching can be said to be effective for increasing students' critical thinking skills if the learning outcomes of students after using student worksheets based on reciprocal teaching are higher than before using student worksheets based on reciprocal teaching.

Based on the effectiveness test using N-Gain obtained results of critical thinking learning of students after using student worksheets based on reciprocal teaching is higher than before using the worksheet of these students. The results of the recapitulation of the average N-Gain in the field trial obtained an average of 0.51 which means that the normalized gain is in the classification of "Medium", then the level of effectiveness is effective. In addition, the results of the analysis of critical thinking indicators indicate the existence of each indicator, namely analyzing, evaluating, identifying, and connecting. The results of this study are in accordance with Lee's (2014: 95) opinion which states that student worksheets can be useful in many ways including academic achievement, for example as a supplement for books, and adding information.

Student worksheets help students to understand the material and improve abilities. The effectiveness of the use of teaching materials on student worksheets based on reciprocal teaching is also strengthened by the results of research conducted by Chen, Y.C, et al. (2017: 133-142) the results of the study show that reciprocal teaching teaching helps students to emphasize general construction and learning through interaction between teacher and students and between students, group spirit of cooperation, and group honor so that those with high ability are willing to lead low ability, while those with low abilities can automatically learn and improve the effectiveness of learning by applying strategies to real practice through the guidance of leaders in the learning process.

\section{CONCLUSION}

Based on data analysis of research and development with the title "The development of student worksheets Based on Reciprocal Teaching to Improve Critical Thinking Ability of Fourth Grade in Public Elementary School" it can be concluded that the products of student worksheets based on reciprocal teaching were developed validally, both theoretically and empirically. Valid theoretically, that has fulfilled conformity with material and media aspects. This is evidenced by the results of the material validation obtaining a value of 95.00 in the "Valid" category, the validation of media experts obtaining a score of 93.00 in the "Valid" category, and the validation of fourth grade teacher in A class with a value of 90.00 in the "Valid" category. Valid empirically that is based on the results of a small group trial there is an increase in student learning outcomes before and after 
using based on reciprocal teaching with an average score at pretest of 59.60 increasing to 77.20 at the posttest. Furthermore, student worksheets based on reciprocal teaching is effectively used in the learning process in fourth grade in A class students of Public Elementary School 2 Sribhawono to improve their critical thinking skills. This is evidenced by the learning outcomes of students in the pretest and posttest scores gaining a gain of 0.51 with the category "Medium".

\section{REFERENCES}

Arends, Richard I. 2012. Learning to Teach. The McGraw-Hill Companies: New York.

Bialik, M \& Fadel, C 2015. Skill For The 21st Century. Center For Curriculum Redesign. Boston

Borg, Walter R., dan Gall, Meredith Damien. 1983. Education Research. New York. 936 hlm.

Chen, Y.C, et al. 2017. Integrating Multimedia Information Technology into Instruction. EURASIA Journal of Mathematics Science and Technology Education ,13(1):133-142.

DePorter, Bobbi. dkk. 2013. Quantum Learning: Membiasakan Belajar Nyaman dan Menyenangkan. Kaifa. Bandung. $274 \mathrm{hlm}$.

Johnson, Elaine B. 2014. CTL Contextual Teaching And Learning. Kaifa. Bandung. 349 hlm.

Lee, Che-Di. 2014. Worksheet Usage, Reading Achievement, Classes' Lack of Readiness, and Science Achievement: A Cross-Country Comparison.International Journal of Education in Mathematics, Science and Technology,2(2), 96-106.

OECD. 2016. PISA 2015 Results in Fokus : Excellence and Equity in Education. Volume I. https://www.oecd.org/pisa/pisa-2015-results-in-focus.pdf.

Romanowski, Michael.H dan Ramzi Nasser. 2012. Critical Thinking and Qatar'sEducation For a New Era: Negotiating Possibilities. International Journal ofCritical Pedagogy, Vol 4 (1):118-134.

Slavin, Robert E. 2011. Psikologi Pendidikan (Teori dan Praktik). Indeks. Jakarta. 348 hlm.

TIMSS. 2016. TIMSS 2015 International Results in Science: Findings From IEA's Trends In International Mathematics and Science study at the Fourth and Eighth Grades. United States. TIMSS \& PIRLS International Study Center.

Trianto. 2012. Mendesain Model Pembelajaran Inovatif-Progrsif. Kencana. Jakarta. $381 \mathrm{hlm}$.

Yen-Ju Hou. 2015. Reciprocal Teaching, Metacognitive Awareness, and Academic Performance in Taiwanese Junior College Students.International Journal of Teaching and Education, 3(4): 15-32.

Yousef, Mohammad, et al. 2016. The Effect of the Reciprocal Teaching Model on Developing Jordanian Students' Reading Comprehension at Mutah University. International Journal of Linguistics. 8 (6): 69-93. 